\title{
Generalized Lipodystrophy
}

National Cancer Institute

\section{Source}

National Cancer Institute. Generalized Lipodystrophy. NCI Thesaurus. Code C131815.

Almost complete absence of subcutaneous and/or visceral adipose tissue. 